\title{
Influence of milk fatty acid composition and process parameters on the quality of ice cream
}

\author{
Karen $\mathrm{Smet}^{1 *}$, Jan De Block ${ }^{1}$, Paul Van Der Meeren ${ }^{2}$, Katleen Raes ${ }^{3}$, \\ Koen Dewettinck ${ }^{4}$, Katleen CoudiJzer ${ }^{1}$ \\ ${ }^{1}$ Technology and Food Science Unit, Institute for Agricultural \\ and Fisheries Research (ILVO), Melle, Belgium \\ ${ }^{2}$ Particle and Interfacial Technology Group, Faculty of Bioscience Engineering, \\ Ghent University, Ghent, Belgium \\ ${ }^{3}$ Research Group EnBiChem, Department of Industrial Engineering and Technology, \\ University College West Flanders, Kortrijk, Belgium \\ ${ }^{4}$ Laboratory of Food Technology and Engineering, Department of Food Safety and Food Quality, \\ Faculty of Bioscience Engineering, Ghent University, Ghent, Belgium
}

Received 15 May 2009 - Revised 18 December 2009 - Accepted 8 January 2010

Published online 18 March 2010

\begin{abstract}
There has been considerable interest in recent years in altering the fatty acid composition of milk fat in dairy products to improve the long-term health of consumers. The objective of this study was to investigate the influence of altering the fatty acid composition and varying two process parameters (homogenization pressure and ageing temperature) on the quality of ice cream. The quality of ice cream ( $8 \%$ fat) was monitored before and after heat shock by assessing fat droplet size, solvent extractable fat content, texture analysis, meltdown tests and sensory analyses. The results suggest that a high solid fat content and low homogenization pressure correlated well with large particles and high amounts of solvent extractable fat, which resulted in firm ice cream with slow melting behaviour and good structure retention. In contrast, ageing temperature did not significantly influence fat destabilization. Following heat shock, the results suggested that the hardness of ice cream was not determined by any of the parameters investigated, but was probably dominated by the amount of ice crystals. A good melting behaviour was retained after heat shock, provided that a strong matrix of destabilized fat was produced during the freezing process. Even though differences could be observed in hardness and melting behaviour for different milk fats or process conditions, these differences were hardly identified by trained sensory panels. These results suggest that high-quality ice cream can be produced with an altered fatty acid composition without any alteration in the conventional production process, provided that ice cream is stored and consumed under ideal circumstances.
\end{abstract}

ice cream / homogenization / ageing temperature / fatty acid composition

摘要 - 脂肪酸组成和工艺参数对冰淇淋质量的影响。摘要 近年来, 关于乳制品中脂肪酸组 成对人体健康产生长期影响的问题引起了人们广泛的关注。本文研究了脂肪酸组成和加工条 件的变化对冰淇淋质量的影响。通过测定热击前后脂肪颗粒大小、溶剂可提取脂肪的含量、质 构分析、塌陷实验和感官评定来评价冰淇淋质量 (含 $8 \%$ 脂肪)。实验结果证明了高固形物含量 和低均质压力与大的脂肪颗粒和高含量的溶剂可提取脂肪具有正相关性, 进而形成的坚硬 冰淇淋具有较慢的溶化性和较好的质构保持性。相反, 老化温度并不能显著地影响脂肪的

*Corresponding author (通讯作者): Karen.smet@ilvo.vlaanderen.be 
不稳定性。本研究中所有的参数对热击后冰淇淋的硬度没有影响, 可能是由于硬度与冰晶 的形成有关。假设由于冷冻过程形成了非常不稳定的脂肪基质，通过热击可以使冰淇淋 保持较好的溶化性。尽管, 脂肪含量和工艺参数的不同对冰淇淋硬度和溶化性还是有影响 的, 但是这种质量上的差异对一些专业的感官评定人员来讲还是难以区别的。研究结果证 明了在理想的贮藏条件和不改变常规工艺参数的前提下, 通过改变脂肪酸组成还是可以生 产出高质量的冰淇淋。

\section{冰淇淋 / 均质 / 老化温度 / 脂肪酸组成}

Résumé - Influence de la composition en acides gras du lait et des paramètres de fabrication sur la qualité de la crème glacée. Modifier la composition en acides gras de la matière grasse des produits laitiers en vue d'améliorer la santé à long terme des consommateurs a récemment fait l'objet de beaucoup d'intérêt. L'objectif de cette étude était de déterminer l'influence de modifications de composition en acides gras et de variations des conditions de fabrication sur la qualité de la crème glacée. La qualité de crèmes glacées ( $8 \%$ de matière grasse) a été suivie avant et après un choc thermique en déterminant la taille des gouttelettes lipidiques, la quantité de matière grasse extractible par solvant, la texture, la fonte et par évaluation sensorielle. Les résultats suggèrent qu'une forte concentration en matière grasse et une faible pression d'homogénéisation étaient bien corrélées avec de grosses gouttelettes lipidiques et de fortes quantités de matière grasse extractible par solvant, donnant ainsi une crème glacée ferme, fondant peu et gardant une bonne structure. Au contraire, la température de conservation n'influençait pas significativement la déstabilisation de la matière grasse. Après un traitement thermique, la dureté de la crème glacée n'était influencée par aucun des paramètres testés, mais était probablement déterminée par la quantité de cristaux de glace. Un bon comportement de fonte était conservé après le choc thermique, à condition qu'une matrice solide de matière grasse déstabilisée soit formée pendant la congélation. Bien que des différences de dureté et de comportement à la fonte aient été induites par les différentes compositions en acides gras et conditions de fabrication mises en œuvre, ces différences n'étaient que difficilement perçues par un panel entraîné d'évaluation sensorielle. Ces résultats suggèrent qu'une crème glacée de haute qualité peut-être produite avec une composition en acides gras modifiée avec un procédé conventionnel, à condition que la crème glacée soit stockée et consommée dans des conditions appropriées.

crème glacée / homogénéisation / température de conservation / composition en acides gras

\section{INTRODUCTION}

Ice cream is a highly desired sweet and frozen mixture consisting of a combination of milk components, sweeteners, stabilizers, emulsifiers and flavours, with a minimal fat content of $8 \%[3,7]$. Since consumers demand healthier products, there is considerable interest in altering the fatty acid composition of milk fat with the overall aim to improve the long-term health of consumers. Important targets involve reducing the amounts of some specific saturated fatty acids (SFAs), especially myristic acid (C14:0) and palmitic acid (C16:0), together with enhancing oleic acid, vaccenic acid (C18:1t11) and rumenic acid (C18:2c9t11)
$[10,19]$. The fatty acid composition of milk fat can be improved by genetic manipulation of the dairy cow, specific feeding strategies or fractionation processes [14].

Although a change in the fatty acid composition is desirable, it may not be immediately possible because fat is a crucial component for both the process conditions and the microstructure of several dairy products, e.g. ice cream [8]. In particular, fat appears to contribute largely to the properties of ice cream during whipping and freezing, especially through the partially coalesced/agglomerated continuous threedimensional network of homogenized globules [11]. Indeed, part of the fat globules surrounds air bubbles and, thus, participates 
in the air phase stabilization [12], while increased levels of fat aggregation are correlated to improved melting resistance [5] and smooth eating textural properties [11]. For partial coalescence and fat aggregation, a certain amount of crystalline fat is required, making the solid:liquid ratio at freezing temperatures an important parameter for ice cream structure formation [6]. A more unsaturated fatty acid composition of milk fat may therefore result in a changed ice cream structure, which was already observed by Adleman and Hartel [2] and Abd El-Rahman et al. [1].

In addition to an altered fatty acid composition, changes in process parameters may also influence fat destabilization and consequently the quality of ice cream. Since new surfaces are formed during homogenization, homogenization conditions may influence fat destabilization and the meltdown characteristics of the ice cream [17, 23]. Sakurai et al. [22] and Kokubo et al. [15, 16] showed that lowered drawing temperatures, increased dasher capacity and speed, and increased overrun resulted in ice cream with a slow meltdown speed and good melting resistance. Therefore, it is important to select the correct process conditions as a function of the composition of the ice cream mix to obtain ice cream with good meltdown characteristics.

The objective of this experiment was to investigate the influence of a changed fatty acid composition and varying process conditions on the quality of ice cream. Milk fat composition was varied using a low-, middleand high-melting milk fat fraction (downstream approach) and milk fat derived from cows fed a diet rich in polyunsaturated fatty acids (PUFAs) (upstream approach). Different processing conditions were achieved using different homogenization pressures (two-step: 5/5, 13/5 and 20/5 MPa) and ageing temperatures $\left(7\right.$ and $\left.2{ }^{\circ} \mathrm{C}\right)$. The quality of ice cream was monitored before and after heat shock by means of fat droplet size, solvent extractable fat content, texture analysis, meltdown tests and sensorial analyses.

\section{MATERIALS AND METHODS}

\subsection{Experimental design}

Four different ice cream recipes were prepared, containing $8 \%$ milk fat (anhydrous milk fat; Royal FrieslandCampina, Klerken, Belgium), $12.2 \%$ milk solids non-fat (skim milk powder; Belgomilk, Langemark, Belgium), 11.8\% sucrose (Tiense Suikerraffinaderij, Tienen, Belgium), 5.7\% glucose/ maltose syrup (mylose DBS8138; MPM De Block, Edegem, Belgium), 0.45\% emulsifier/stabilizer (mono- and diglycerides, locust bean gum and guar gum; Swissgum F-6038; Ingrizo NV, Mariakerke, Belgium), $0.01 \%$ vanillin (EuroVanillin, Sarpsborg, Norway) and $61.8 \%$ water. The ice cream recipes only differed in their milk fat composition (Tab. I), which was pursued with an upstream and downstream approach. Upstream regulation was done by changing the feed of the cows. A control milk fat (milk fat $\mathrm{C}$ ) was produced by feeding the cows a standard diet, while a more unsaturated milk fat (milk fat $U$ ) was obtained from cows fed a diet rich in PUFAs (extruded linseed). In contrast, a low-melting milk fat fraction (milk fat L) and a high-melting milk fat fraction (milk fat $\mathrm{H}$ ) were derived from milk fat $\mathrm{C}$ using multistep dry fractionation, which is a downstream approach.

After mixing the ingredients at $50{ }^{\circ} \mathrm{C}$, the ice cream mixes $(60 \mathrm{~L})$ were homogenized at different pressures $\left(65^{\circ} \mathrm{C}\right.$; twostep: $5 / 5,13 / 5$ and $20 / 5 \mathrm{MPa})$ and pasteurized $\left(15 \mathrm{~s}, 85^{\circ} \mathrm{C}\right.$; APV Paraflow Pilot; APV, Getzville, NY, USA), after which the mixes were cooled down to $17{ }^{\circ} \mathrm{C}$. During ageing at different refrigerator temperatures $\left(7\right.$ and $2{ }^{\circ} \mathrm{C}$ ), the temperature in the ice cream mix barrels exponentially decreased to 8.1 and $3.8^{\circ} \mathrm{C}$, respectively, after $18 \mathrm{~h}$. The aged ice cream 
Table I. Melting point $\left({ }^{\circ} \mathrm{C}\right.$, bulk fat), solid fat content (\% SFC, bulk fat) at different stages in the production process of ice cream and fatty acid composition ( $\mathrm{wt} \%$, ice cream) of control milk fat (C), milk fat enriched with unsaturated fatty acids (U), a low-melting milk fat fraction (L) and a highmelting milk fat fraction $(\mathrm{H})$. Results are the mean of three or four determinations. SEM, standard error of means ${ }^{1} ; \mathrm{SFC}_{-18}{ }^{\circ} \mathrm{C}$, $\mathrm{SFC}$ after storage at $-18{ }^{\circ} \mathrm{C} ; \mathrm{SFC}_{3.8}{ }^{\circ} \mathrm{C}, \mathrm{SFC}$ after ageing at $2{ }^{\circ} \mathrm{C}$; and $\mathrm{SFC}_{8.1{ }^{\circ} \mathrm{C}}$, SFC after ageing at $7{ }^{\circ} \mathrm{C}$.

\begin{tabular}{lcccccc}
\hline & C fat & U fat & L fat & H fat & SEM & $P$ value \\
\hline Melting point $\left({ }^{\circ} \mathrm{C}\right)$ & $35.43^{\mathrm{b}}$ & $36.56^{\mathrm{b}}$ & $18.77^{\mathrm{c}}$ & $40.48^{\mathrm{a}}$ & 2.02 & $<0.001$ \\
$\mathrm{SFC}_{-18}{ }^{\circ} \mathrm{C}(\%)$ & $83.47^{\mathrm{b}}$ & $82.53^{\mathrm{b}}$ & $76.98^{\mathrm{c}}$ & $85.80^{\mathrm{a}}$ & 0.99 & $<0.001$ \\
$\mathrm{SFC}_{3.8^{\circ} \mathrm{C}(\%)}$ & $39.03^{\mathrm{b}}$ & $38.80^{\mathrm{b}}$ & $19.73^{\mathrm{c}}$ & $54.15^{\mathrm{a}}$ & 3.69 & $<0.001$ \\
$\mathrm{SFC}_{8.1}{ }^{\circ} \mathrm{C}(\%)$ & $36.76^{\mathrm{b}}$ & $34.88^{\mathrm{c}}$ & $9.71^{\mathrm{d}}$ & $53.79^{\mathrm{a}}$ & 4.74 & $<0.001$ \\
$\mathrm{SFA}^{2}(\%)$ & $64.5^{\mathrm{b}}$ & $61.8^{\mathrm{c}}$ & $58.1^{\mathrm{d}}$ & $70.2^{\mathrm{a}}$ & 1.3 & $<0.001$ \\
$\mathrm{MUFA}^{3}(\%)$ & $32.4^{\mathrm{c}}$ & $34.0^{\mathrm{b}}$ & $37.4^{\mathrm{a}}$ & $26.8^{\mathrm{d}}$ & 1.0 & $<0.001$ \\
$\mathrm{PUFA}^{4}(\%)$ & $3.83^{\mathrm{c}}$ & $4.15^{\mathrm{b}}$ & $4.53^{\mathrm{a}}$ & $3.02^{\mathrm{d}}$ & 0.15 & $<0.001$ \\
Total CLA $^{5}(\%)$ & $1.41^{\mathrm{b}}$ & $1.52^{\mathrm{a}}$ & $1.31^{\mathrm{b}}$ & $1.03^{\mathrm{c}}$ & 0.05 & $<0.001$ \\
$\omega 6^{6}(\%)$ & $1.77^{\mathrm{b}}$ & $1.74^{\mathrm{b}}$ & $2.42^{\mathrm{a}}$ & $1.47^{\mathrm{c}}$ & 0.09 & $<0.001$ \\
$\omega 3^{7}(\%)$ & $0.662^{\mathrm{c}}$ & $0.884^{\mathrm{a}}$ & $0.808^{\mathrm{b}}$ & $0.516^{\mathrm{d}}$ & 0.038 & $<0.001$ \\
$\omega 6 / \omega 3$ & $2.68^{\mathrm{b}}$ & $1.98^{\mathrm{c}}$ & $3.00^{\mathrm{a}}$ & $2.85^{\mathrm{a}, \mathrm{b}}$ & 0.43 & $<0.001$ \\
\hline
\end{tabular}

${ }^{1}$ Means with different letters (a, b, $\mathrm{c}$ and $\mathrm{d}$ ) in the same row differ significantly (Duncan, $P<0.05$ ).

${ }^{2}$ Saturated fatty acids; sum of C4:0, C6:0, C8:0, C10:0, C12:0, C14:0, 12mC14:0, 13mC14:0, C15:0, $\mathrm{C} 16: 0,14 \mathrm{mC} 16: 0,15 \mathrm{mC} 16: 0, \mathrm{C} 17: 0, \mathrm{C} 18: 0, \mathrm{C} 20: 0, \mathrm{C} 21: 0, \mathrm{C} 22: 0$ and $\mathrm{C} 24: 0$.

${ }^{3}$ MUFAs; sum of $\mathrm{C} 14: 1 \mathrm{c} 9, \mathrm{C} 16: 1 \mathrm{t} 9, \mathrm{C} 16: 1 \mathrm{c} 9, \mathrm{C} 17: 1 \mathrm{c} 9, \mathrm{C} 18: 1$ total trans, C18:1c9, C18:1c11, C20:1c11 and $\mathrm{C} 22: 1 \mathrm{c} 13$.

${ }^{4}$ PUFAs; sum of $\mathrm{C} 18: 2 \mathrm{c} 9 \mathrm{c} 12, \mathrm{C} 18: 3 \mathrm{c} 6 \mathrm{c} 9 \mathrm{c} 12, \mathrm{C} 18: 3 \mathrm{c} 9 \mathrm{c} 12 \mathrm{c} 15, \mathrm{C} 18: 2 \mathrm{c} 9 \mathrm{t} 12, \mathrm{C} 18: 2 \mathrm{t} 10 \mathrm{c} 12, \mathrm{C} 20: 2 \mathrm{c} 11 \mathrm{c} 14$, $\mathrm{C} 20: 3 \mathrm{c} 8 \mathrm{c} 11 \mathrm{c} 14, \mathrm{C} 20: 4 \mathrm{c} 5 \mathrm{c} 8 \mathrm{c} 11 \mathrm{c} 15, \mathrm{C} 20: 5 \mathrm{c} 5 \mathrm{c} 8 \mathrm{c} 11 \mathrm{c} 14 \mathrm{c} 17$ and $\mathrm{C} 22: 5 \mathrm{c} 7 \mathrm{c} 10 \mathrm{c} 13 \mathrm{c} 16 \mathrm{c} 19$.

${ }^{5}$ Conjugated linoleic acid; sum of $\mathrm{C} 18: 2 \mathrm{c} 9, \mathrm{t} 11$ and $\mathrm{C} 18: 2 \mathrm{t} 10, \mathrm{c} 12$.

${ }^{6} \mathrm{Sum}$ of $\mathrm{C} 18: 2 \mathrm{c} 9 \mathrm{c} 12, \mathrm{C} 18: 2 \mathrm{c} 6 \mathrm{c} 9 \mathrm{c} 12, \mathrm{C} 20: 2 \mathrm{c} 11 \mathrm{c} 14, \mathrm{C} 20: 3 \mathrm{c} 8 \mathrm{c} 11 \mathrm{c} 14$ and $\mathrm{C} 20: 4 \mathrm{c} 5 \mathrm{c} 8 \mathrm{c} 11 \mathrm{c} 14$.

${ }^{7}$ Sum of $\mathrm{C} 18: 3 \mathrm{c} 9 \mathrm{c} 12 \mathrm{c} 15, \mathrm{C} 20: 5 \mathrm{c} 5 \mathrm{c} 8 \mathrm{c} 11 \mathrm{c} 14 \mathrm{c} 17$ and $\mathrm{C} 22: 5 \mathrm{c} 7 \mathrm{c} 10 \mathrm{c} 13 \mathrm{c} 16 \mathrm{c} 19$.

mixes were frozen in a continuous freezer (Gelmark Hoyer 160; Alfa Laval Hoyer, Italy) to a draw temperature of $-5.5^{\circ} \mathrm{C}$, while an overrun of $100 \%$ was aimed for. Ice cream samples were then hardened to $-22{ }^{\circ} \mathrm{C}$ for at least $24 \mathrm{~h}$ and finally stored at $-18{ }^{\circ} \mathrm{C}$ until analysis.

Half of the ice cream samples were subjected to a heat shock procedure in order to evaluate the influence of the different ice cream recipes and process conditions on the functional stability of ice cream under stress conditions. The temperature varied from $-18{ }^{\circ} \mathrm{C}$ to $-9{ }^{\circ} \mathrm{C}$ to $-18{ }^{\circ} \mathrm{C}$ with a complete cycle time of $48 \mathrm{~h}$. Five cycles were performed, after which the samples were stored at $-18{ }^{\circ} \mathrm{C}$ until analysis.

\subsection{Methods}

\subsubsection{Fatty acid composition}

Milk fat was extracted from ice cream by the Röse-Gottlieb procedure, followed by methylation of the extracted lipids. These fatty acid methyl esters were analysed by gas chromatography $[13,24]$.

\subsubsection{Solid fat content of milk fat}

The solid fat content (SFC) determination of the bulk fat was performed using pulsed nuclear magnetic resonance (pNMR) with a Minispec PC 20 (Bruker, Karlsruhe, Germany). Liquefied fat was transferred into 
pNMR tubes and held at $65^{\circ} \mathrm{C}$ for $30 \mathrm{~min}$ to eliminate any thermal history. Afterwards, the pNMR tubes were quenched and cooled with liquid nitrogen and placed in a water bath at $-20^{\circ} \mathrm{C}$. After an incubation of $1 \mathrm{~h}$, the SFC was determined with pNMR. Then, the temperature of the water bath was increased with $5{ }^{\circ} \mathrm{C}$ and again, the SFC was determined after $1 \mathrm{~h}$ of incubation. This procedure was repeated until the anhydrous milk fat was totally liquefied.

To investigate the SFC of ice cream (mix) after ageing $\left(3.8\right.$ and $\left.8.1^{\circ} \mathrm{C}\right)$ and hardening $\left(-18{ }^{\circ} \mathrm{C}\right)$, bulk fat was exposed to simulated conditions representative of what ice cream went through, while its SFC was monitored with pNMR. The exponential decay of the temperature during ageing was imitated with a cryostat, while the SFC after hardening was determined after $48 \mathrm{~h}$ at $-18{ }^{\circ} \mathrm{C}$. All measurements were done in triplicate.

\subsubsection{Melting point of milk fat}

The melting point of milk fat was obtained with differential scanning calorimetry (DSC; TA Q1000; TA Instruments, New Castle, USA). The DSC was calibrated with indium (TA Instruments, New Castle, USA), azobenzene (Sigma-Aldrich, Bornem, Belgium) and undecane (Acros Organics, Geel, Belgium) before analyses. Nitrogen was used to purge the system. The sample was sealed in a hermetic aluminium pan and an empty pan was used as a reference. The applied timetemperature programme was as follows: holding at $65{ }^{\circ} \mathrm{C}$ for $15 \mathrm{~min}$ to ensure a completely liquid state, cooling at $10{ }^{\circ} \mathrm{C} \mathrm{min}^{-1}$ to $-50{ }^{\circ} \mathrm{C}$, holding for $5 \mathrm{~min}$ and then heating at $20{ }^{\circ} \mathrm{C} \mathrm{min}-1$ to $65{ }^{\circ} \mathrm{C}$. The melting point was determined by measuring the onset point on the melting curve. This procedure was done in fivefold.

\subsubsection{Overrun of ice cream}

Overrun was monitored at draw by comparing the weight of ice cream mix and ice cream in a fixed volume container. Overrun (in \%) was calculated as follows:

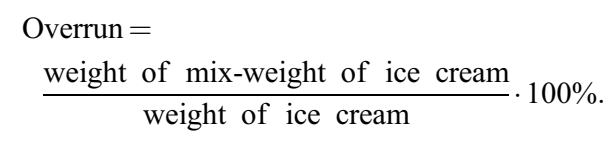

After hardening, overrun was measured more accurately by correcting for the volume of air at the top of the container. For every batch, overrun was determined in 10-fold.

\subsubsection{Texture analysis}

Firmness of the ice cream samples $\left(500 \mathrm{~mL} ;-15^{\circ} \mathrm{C}\right)$ was measured by penetration of a vertical sheet (stainless steel; $30 \times 1 \mathrm{~mm}$ ) into the ice cream to a depth of $20 \mathrm{~mm}$ at a constant speed of $20 \mathrm{~mm} \cdot \mathrm{min}^{-1}$ with a Texture Analyser (LF-Plus; Lloyd Instruments Ltd., Hants, UK). For every batch, 10 different samples were analysed at three different places in the ice cream box.

\subsubsection{Fat droplet size}

The size distribution of fat globules was determined using a Mastersizer S (Malvern Instruments, Malvern, UK) equipped with a $300 \mathrm{RF}$ lens. The dilution of the emulsion in the sample chamber with demineralized water was $\sim 1: 1000$, while the settings for pumping, stirring and ultrasound measured $750 \mathrm{rpm}, 300 \mathrm{rpm}$ and $0 \%$, respectively. The refractive index values for milk fat and water were fixed at 1.482 and 1.33 , respectively, whereas the imaginary refractive index of the dispersed phase was set to 0.01 . Polydisperse analysis was selected. Melted ice cream fat globule's mean diameter (evaluated by the volume-weighted average diameter, $D_{4,3}$ ) was recorded as well as the cumulative percentage of fat aggregates with diameters greater than 2.0 or $4.0 \mu \mathrm{m}$, 
for homogenization pressures of $13 / 5$ or 20 / $5 \mathrm{MPa}$ and 5/5 MPa, respectively. Boundaries were set to 2.0 and $4.0 \mu \mathrm{m}$, since all particles in the ice cream mix had a smaller diameter than these particular limits, indicating that particles with diameters greater than 2.0 or $4.0 \mu \mathrm{m}$, respectively, were originating from the formation of aggregates.

\subsubsection{Solvent extractable fat content}

A mixture of petroleum ether and diethyl ether $(1: 1 ; \mathrm{v} / \mathrm{v} ;$ J.T. Baker, Deventer, The Netherlands; Panreac, Barcelona, Spain) was used as a solvent in order to partially extract fat from melted ice cream samples. About $10 \mathrm{~g}$ of the frozen ice cream were weighed into a $150 \mathrm{~mL}$ separation flask. Samples were thawed for $15 \mathrm{~min}$ at $40{ }^{\circ} \mathrm{C}$. After thawing, $5 \mathrm{~mL}$ of water and $50 \mathrm{~mL}$ of ether mixture were added and the mixture was slowly agitated for $1 \mathrm{~min}$. Subsequently, the separation flasks were rotated at about $40 \times g$ for $5 \mathrm{~min}$ (Sorvall RC 26 Plus, Global Medical Instrumentation Inc., Ramsey, MN, USA), after which the ether phase was transferred into dry and calibrated conical flasks by means of a $10 \mathrm{~mL}$ pipette. The extraction, starting with the addition of $50 \mathrm{~mL}$ of ether mixture to the water phase, was repeated. The pooled extracts were kept on a heating plate in a fume hood until visually determined as dry, and the conical flasks were then dried at $104{ }^{\circ} \mathrm{C}$ for $1 \mathrm{~h}$. They were transferred to the sample dry keeper for $30 \mathrm{~min}$ and weighed. The percentage of total extractable fat was calculated.

\subsubsection{Meltdown test}

The meltdown tests were carried out in an acclimatized chamber at $20^{\circ} \mathrm{C}$. The ice cream samples $\left(500 \mathrm{~mL} ;-18{ }^{\circ} \mathrm{C}\right)$ were placed on a grid (material: stainless steel; size: $16 \mathrm{~cm} \times 18 \mathrm{~cm}$; hole diameter: $2 \mathrm{~mm}$ ) and a beaker was placed underneath the grid on scales to collect and weigh the drip losses. Weights were recorded every
$10 \mathrm{~min}$ for $150 \mathrm{~min}$. Pictures to evaluate the shape of the ice cream samples were taken every $30 \mathrm{~min}$. The analysis was performed in triplicate.

\subsubsection{Sensory analysis}

Sensory analysis was used to evaluate hardness, mouth feel, melting behaviour and preference between ice cream with a different fatty acid composition or a different processing. The influence of fatty acid composition on the sensorial quality of ice cream was investigated by comparing the different milk fats for all six process conditions (after hardening). The influence of homogenization pressure was examined for both milk fat $\mathrm{C}$ and $\mathrm{U}$, aged at 7 and $2{ }^{\circ} \mathrm{C}$, respectively (after hardening and heat shock). Finally, the influence of ageing temperature was investigated for both milk fat $\mathrm{C}$ and $\mathrm{U}$ for a homogenization pressure of 13/5 MPa (after hardening and heat shock). The panel consisted of 30 people (11 men and 19 women) who were staff of the Institute for Agricultural and Fisheries Research. Their mean age was 36 years (range 1963 years). All panellists had earlier experience in sensory evaluation of ice cream. Evaluations were conducted in a sensorial cabinet that was equipped with individually partitioned booths. Ice cream samples were served at $-15^{\circ} \mathrm{C}$. Depending on the tested combination, two, three or four ice cream samples were served and the panellists were asked to classify the samples for hardness (scale: too soft-too hard), mouth feel (scale: too watery-too sticky), melting behaviour (scale: too slow-too fast) and preference (scale: poor-good). The processing of the results was done based on the tables of Kramer et al. [18] for $\alpha=0.05$.

\subsection{Statistical analysis}

Statistical analysis of the data was performed using the SPSS statistical package, release 16.0 (SPSS, Chicago, IL, USA). 


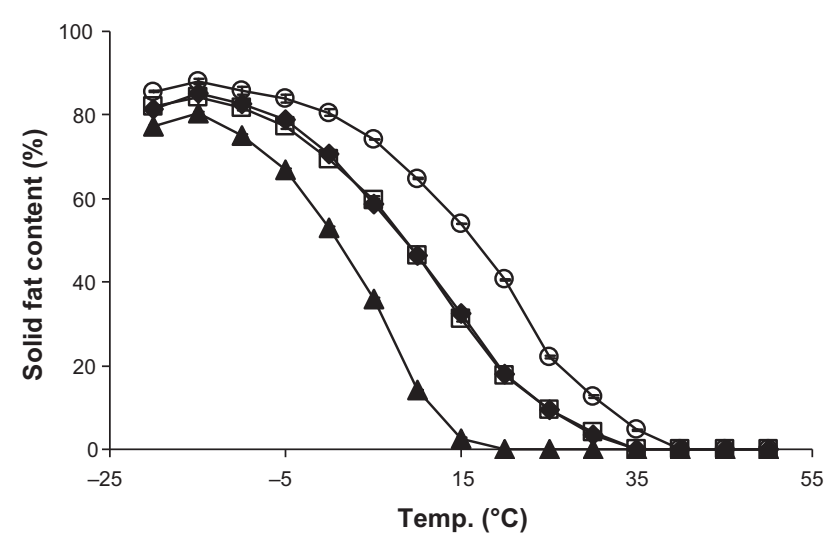

Figure 1. SFC as a function of temperature determined with pulsed nuclear magnetic resonance for control milk fat $(\diamond)$, milk fat enriched with unsaturated fatty acids $(\square)$, low-melting milk fat fraction $(\Delta)$ and high-melting milk fat fraction (०). Error bars indicate $\pm 1 \mathrm{SD}$ based on three determinations.

The characteristics of the different milk fats (fatty acid composition, melting point, $\mathrm{SFC}_{-18}{ }^{\circ} \mathrm{C}, \mathrm{SFC}_{8.1{ }^{\circ} \mathrm{C}}$ and $\mathrm{SFC}_{3.8}{ }^{\circ} \mathrm{C}$ ) were analysed using one-way ANOVA with milk fat as fixed factor. Comparison of means was performed using Duncan as post hoc test $(P<0.05)$. Relationships between the different parameters describing milk fat, ice cream mix and ice cream (fatty acid composition, melting point, SFC, volumeweighted average diameter of ice cream mix and ice cream, $\%$ of aggregates, $\%$ of solvent extractable fat, hardness and $\%$ of drip) for fresh ice cream and after heat shock were evaluated using Pearson correlations at a significance level of $5 \%$.

\section{RESULTS AND DISCUSSION}

\subsection{Chemical and physical characterization of milk fat}

All four ice cream recipes had the same composition, except for the fat fraction. Table I shows the differences in fatty acid composition between the different recipes. Obviously, milk fat $\mathrm{L}$ and $\mathrm{H}$, produced by multistep dry fractionation, showed the lowest and highest SFA fraction, respectively, and the highest and lowest monounsaturated fatty acid (MUFA) and PUFA fraction, respectively. In contrast, milk fat $\mathrm{C}$ and $\mathrm{U}$ contained intermediary values for SFA, MUFA and PUFA fraction. However, when comparing milk fat $\mathrm{C}$ and $\mathrm{U}$ more carefully, milk fat $U$ showed a significantly lower fraction of SFA, mainly due to a decreased fraction of C8:0, C10:0, C12:0, C14:0 and $\mathrm{C} 16: 0$, even though a significant increase in $\mathrm{C} 18: 0$ could be observed. In addition, the MUFA fraction of milk fat $U$ was significantly higher because of a higher fraction of C18:1c9 and total trans C18:1, while a higher PUFA fraction was related to an increased content of rumenic and linolenic acids (data not shown).

Assuming the differences in fatty acid composition, changes in the physical behaviour of milk fat could be expected. Therefore, the SFC profile of bulk fat was measured for all four milk fats from $-20{ }^{\circ} \mathrm{C}$ until melting (Fig. 1). Milk fat $\mathrm{H}$ clearly showed the highest SFC values for the whole temperature range, whereas milk fat $\mathrm{L}$ contained the lowest amount of SFC. For milk 
Table II. Volume-weighted average diameter, $D_{4,3}(\mu \mathrm{m})$ for ice cream mix made from control milk fat $(\mathrm{C})$, milk fat enriched with unsaturated fatty acids $(\mathrm{U})$, a low-melting milk fat fraction $(\mathrm{L})$ and a high-melting milk fat fraction $(\mathrm{H})$ at different levels of homogenization pressure and ageing temperature. Results are expressed as mean $( \pm \mathrm{SD}) ; P_{\text {hom }}$, homogenization pressure $(\mathrm{MPa}) ; T_{\text {ageing, }}$, ageing temperature $\left({ }^{\circ} \mathrm{C}\right)$.

\begin{tabular}{lccccc}
\hline$P_{\text {hom }}(\mathrm{MPa})$ & $T_{\text {ageing }}\left({ }^{\circ} \mathrm{C}\right)$ & $\mathrm{C}$ mix & $\mathrm{U}$ mix & $\mathrm{L}$ mix & $\mathrm{H}$ mix \\
\hline $5 / 5$ & $(-)^{1}$ & $1.02 \pm 0.23^{2}$ & $0.95 \pm 0.11$ & $0.95 \pm 0.11$ & $1.15 \pm 0.10$ \\
& 7 & $1.20 \pm 0.01$ & $1.06 \pm 0.01$ & $1.12 \pm 0.01$ & $1.00 \pm 0.01$ \\
& 2 & $0.83 \pm 0.01$ & $1.14 \pm 0.22$ & $0.87 \pm 0.02$ & $0.98 \pm 0.02$ \\
$13 / 5$ & $(-)$ & $0.56 \pm 0.03$ & $0.59 \pm 0.02$ & $0.57 \pm 0.01$ & $0.56 \pm 0.02$ \\
& 7 & $0.59 \pm 0.01$ & $0.59 \pm 0.01$ & $0.59 \pm 0.01$ & $0.59 \pm 0.01$ \\
& 2 & $0.55 \pm 0.01$ & $0.59 \pm 0.01$ & $0.58 \pm 0.01$ & $0.58 \pm 0.01$ \\
$20 / 5$ & $(-)$ & $0.53 \pm 0.03$ & $0.48 \pm 0.02$ & $0.49 \pm 0.02$ & $0.51 \pm 0.05$ \\
& 7 & $0.55 \pm 0.01$ & $0.54 \pm 0.05$ & $0.52 \pm 0.01$ & $0.52 \pm 0.01$ \\
& 2 & $0.53 \pm 0.01$ & $0.52 \pm 0.01$ & $0.52 \pm 0.01$ & $0.59 \pm 0.01$ \\
\hline
\end{tabular}

$1(-)$, ice cream mix before ageing.

2 Mean of 2-4 determinations.

fat $\mathrm{C}$ and $\mathrm{U}$, intermediary values for SFC could be observed. Surprisingly, the SFC profile of both these milk fats was very similar. This is probably due to the higher trans C18:1 proportion in milk fat $\mathrm{U}$, despite its lower SFA proportion compared to milk fat C. Indeed, it is known that trans fatty acids have similar melting profiles as SFA. In addition to the SFC profile, the melting point of the different bulk fats was also determined (Tab. I). These results were in agreement with the SFC profile of the different milk fats. Finally, the SFC value of the bulk fat at different moments in the production process was determined (Tab. I). After ageing at $7{ }^{\circ} \mathrm{C}$, large differences in SFC were observed for the different milk fats. Milk fat $\mathrm{L}$ only contained $9.7 \%$ of solid fat, while for milk fat $\mathrm{H} 53.8 \%$ of solid fat was observed. Again, milk fat $\mathrm{C}$ and $\mathrm{U}$ had intermediary values. However, when comparing the SFC of the bulk fat after ageing at $2{ }^{\circ} \mathrm{C}$ with the values for ageing at $7{ }^{\circ} \mathrm{C}$, only small differences could be observed, except for milk fat $\mathrm{L}$, for which an increase of $10 \%$ SFC was measured. After storage of the bulk fat at $-18{ }^{\circ} \mathrm{C}$, most of the fat was solid (from $77 \%$ to $86 \%$ ) for all different milk fat types.

\subsection{Physicochemical characterization of ice cream mix}

In addition to the characterization of the different milk fats, the physicochemical behaviour of ice cream mixes was investigated by monitoring the particle size before and after ageing (Tab. II). The particle size $\left(D_{4,3}\right)$ of ice cream mix was not significantly influenced by milk fat type $(P=0.954)$ or by ageing $(P=0.380)$, although it was significantly altered by homogenization pressure $(P<0.001)$. At $5 / 5 \mathrm{MPa}$, the $D_{4,3}$ measured $1.02( \pm 0.15) \mu \mathrm{m}$, while a $D_{4,3}$ of 0.58 $( \pm 0.02)$ and $0.52( \pm 0.03) \mu \mathrm{m}$ could be observed at $13 / 5$ and $20 / 5 \mathrm{MPa}$, respectively. Also Bazmi et al. [4] could not detect a significant influence of ageing on particle size, even though they observed slightly smaller particles in ice cream mix prepared from milk fat enriched with an olein fraction compared to a control milk fat and milk fat enriched with a stearin fraction. 
In addition, Koxholt et al. [17] reported an inverse relationship between homogenization pressure and particle size, which was similar to our findings and followed the homogenization theory.

\subsection{Physicochemical characterization of ice cream}

In ice cream, the overrun is an important quality parameter. Therefore, the overrun was monitored during draw and after hardening. An overall overrun of $101.1( \pm 3.8) \%$ could be observed, while no significant differences could be reported between the four fat types $(P=0.451)$.

In addition to the overrun, particle size of fat globules, cumulative percentage of aggregates and percentage of solvent extractable fat in ice cream were measured as a function of milk fat type, homogenization pressure, ageing temperature and storage. The obtained results were correlated against storage conditions (fresh - heat shock) and ageing temperature $\left(7-2^{\circ} \mathrm{C}\right)$. Pearson correlations of $0.92-0.95$ and 0.82-0.90 could be observed for storage conditions and ageing temperature, respectively. These high correlations are suggesting that storage conditions and ageing temperature are not significantly influencing the measured parameters. Therefore, results were only discussed for one condition (fresh ice cream, aged at $7^{\circ} \mathrm{C}$; Fig. 2).

Important differences in particle size, cumulative percentage of aggregates and solvent extractable fat content of ice cream could be observed depending on the milk fat composition and the applied homogenization pressure. Irrespective of the milk fat composition, the lowest homogenization pressure $(5 / 5 \mathrm{MPa})$ produced the highest fat destabilization, probably as a result of the large fat droplets. In contrast, only a limited amount of fat was destabilized for intermediate homogenization pressures $(13 / 5 \mathrm{MPa})$, which are usually applied in the ice cream industry. Finally, high homogenization pressures (20/5 MPa) again resulted in higher fat destabilization. At these higher pressures, more membrane was needed to coat the surface of the fat droplets. This may result in a better distribution of the emulsifier, inducing a higher fat destabilization. When comparing ice cream produced with different milk fats, milk fat with a rather high SFC (milk fat $\mathrm{C}$, U and $\mathrm{H}$ ) resulted in large particles and a high content of aggregates and solvent extractable fat, while for ice cream produced with milk fat L, only small particles and a limited amount of aggregates and solvent extractable fat could be detected.

Relationships between the physicochemical characteristics of ice cream and the physical and chemical composition of milk fat and ice cream mix could also be revealed by calculating the Pearson correlations between these parameters (Tab. III). A significant positive correlation could be observed between SFC of the bulk fat and percentage of aggregates, while the correlation with particle size and percentage of solvent extractable fat was not significant under the studied experimental design. Since particle size, percentage of aggregates and percentage of solvent extractable fat are all parameters describing fat destabilization, these results are suggesting that an appropriate ratio of solid: liquid fat must be attained during ageing to induce coalescence of fat during the freezing process. This is also confirming the theory of Darling [9], who suggested that a partially crystalline fat droplet is needed to promote coalescence of fat globules during freezing. As a result, crystals have the ability to distort the surface of the fat globule and these distortions, then, pierce the film between two colliding globules and wet the interface to allow sufficient liquid fat to cement the colliding globules together. Since milk fat L contained very low SFC at ageing temperature, very limited amounts of crystals were formed inducing only a limited amount 

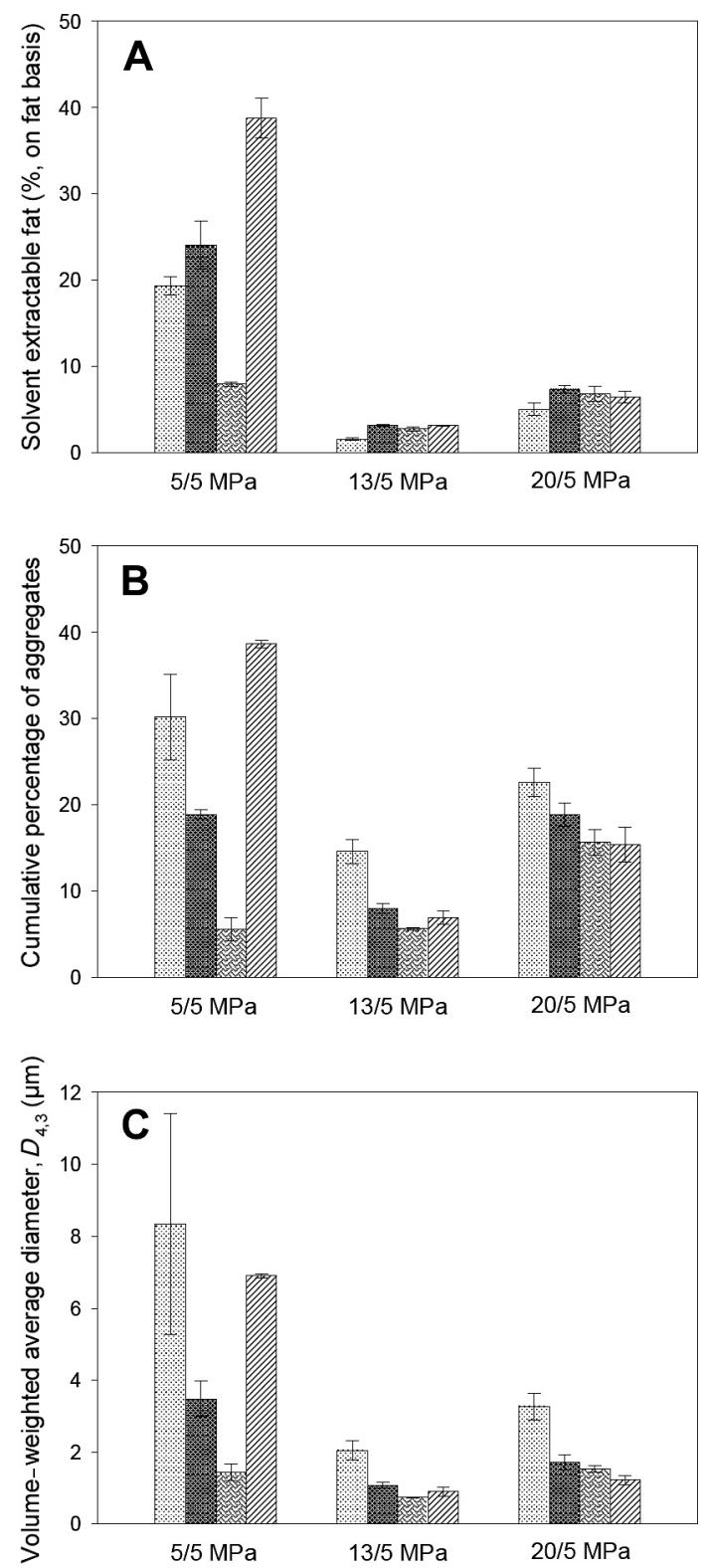

Figure 2. (A) percentage of solvent extractable fat (on fat basis); (B) cumulative percentage of aggregates with diameter greater than 2.0 or $4.0 \mu \mathrm{m}$ for a homogenization pressure of $13 / 5$ and $20 / 5 \mathrm{MPa}$ or $5 / 5 \mathrm{MPa}$, respectively; (C) volume-weighted average diameter, $D_{4,3}(\mu \mathrm{m})$, for fresh ice cream aged at $7{ }^{\circ} \mathrm{C}$ with different levels of homogenization pressure $(5 / 5 \mathrm{MPa}, 13 / 5 \mathrm{MPa}$ and

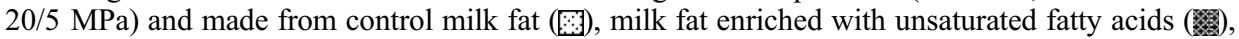
a low-melting milk fat fraction (图) and a high-melting fat fraction (团). 
Table III. Pearson correlation matrix between different methods measuring features of milk fat, ice cream mix and ice cream made from control milk fat, milk fat enriched with unsaturated fatty acids, a low-melting milk fat fraction and a high-melting milk fat fraction for different levels of homogenization pressure $(5 / 5,13 / 5$ and $20 / 5 \mathrm{MPa})$ and ageing temperature $\left(2\right.$ and $\left.7{ }^{\circ} \mathrm{C}\right)$, calculated for fresh ice cream and after heat shock. Significant correlations $(P<0.05)$ are written in bold. SFA, saturated fatty acid content of ice cream (\%); MUFA, monounsaturated fatty acid content of ice cream (\%); polyunsaturated fatty acid, PUFA content of ice cream $(\%) ; T_{\mathrm{m}}$, melting point of milk fat $\left({ }^{\circ} \mathrm{C}\right) ; \mathrm{SFC}_{\mathrm{ag}}$, $\mathrm{SFC}$ of bulk fat after ageing (\%); $\mathrm{SFC}_{\mathrm{fr}}$, $\mathrm{SFC}$ of bulk fat after hardening at $-18{ }^{\circ} \mathrm{C}(\%) ; D_{4,3} \mathrm{mix}$, volume-weighted average diameter of ice cream mix after ageing $(\mu \mathrm{m})$; $D_{4,3}$ ice, volume-weighted average diameter of ice cream $(\mu \mathrm{m})$; \%aggr, cumulative percentage of aggregates with diameter greater than 2.0 or $4.0 \mu \mathrm{m}$ for a homogenization pressure of $13 / 5$ and $20 / 5 \mathrm{MPa}$ or $5 / 5 \mathrm{MPa}$, respectively; $\%$ fat $t_{\text {extr, }}$, percentage of solvent extractable fat (on fat basis); hardness, hardness $(N)$ at $-15{ }^{\circ} \mathrm{C}$; and \%drip, percentage of drip after 150 min at $20{ }^{\circ} \mathrm{C}$.

SFA MUFA PUFA $T_{\mathrm{m}} \quad \mathrm{SFC}_{\mathrm{ag}} \quad \mathrm{SFC}_{\mathrm{fr}} D_{4,3} \operatorname{mix} \quad D_{4,3}$ ice $\%$ aggr $\%$ fat $_{\text {extr }}$ Hardness \%drip

\begin{tabular}{|c|c|c|c|c|c|c|c|c|c|c|c|c|}
\hline \multicolumn{13}{|c|}{ Fresh ice cream } \\
\hline SFA & - & -0.99 & -0.99 & 0.84 & 0.94 & 0.93 & 0.11 & 0.39 & 0.52 & 0.27 & 0.45 & $-\mathbf{0 . 4 3}$ \\
\hline MUFA & -0.99 & - & 0.99 & -0.84 & -0.94 & -0.92 & -0.11 & -0.38 & -0.51 & -0.28 & -0.44 & 0.43 \\
\hline PUFA & -0.99 & 0.99 & - & $-\mathbf{0 . 8 0}$ & -0.92 & -0.90 & -0.11 & -0.38 & $-\mathbf{0 . 5 0}$ & -0.27 & -0.45 & 0.41 \\
\hline$T_{\mathrm{m}}$ & 0.84 & -0.84 & $-\mathbf{0 . 8 0}$ & - & 0.94 & 0.98 & 0.08 & 0.38 & $\mathbf{0 . 5 1}$ & 0.30 & 0.35 & -0.49 \\
\hline $\mathrm{SFC}_{\mathrm{ag}}$ & 0.94 & -0.94 & -0.92 & 0.94 & - & 0.97 & 0.08 & 0.37 & 0.50 & 0.31 & 0.48 & -0.44 \\
\hline $\mathrm{SFC}_{\mathrm{fr}}$ & 0.93 & -0.92 & -0.90 & 0.98 & 0.97 & - & 0.09 & 0.41 & 0.54 & 0.28 & 0.40 & -0.49 \\
\hline$D_{4,3} \operatorname{mix}$ & 0.11 & -0.11 & -0.11 & 0.08 & 0.08 & 0.09 & - & 0.79 & 0.59 & 0.77 & 0.12 & -0.37 \\
\hline$D_{4,3}$ ice & 0.39 & -0.38 & -0.38 & 0.38 & 0.37 & 0.41 & 0.79 & - & 0.94 & 0.82 & 0.29 & -0.62 \\
\hline$\%$ aggr & 0.52 & -0.51 & -0.50 & 0.51 & 0.50 & 0.54 & 0.59 & 0.94 & - & 0.79 & 0.37 & -0.77 \\
\hline$\% \mathrm{fat}_{\text {extr }}$ & 0.27 & -0.28 & -0.27 & 0.30 & 0.31 & 0.28 & 0.77 & 0.82 & 0.79 & - & 0.41 & -0.56 \\
\hline Hardness & 0.45 & -0.44 & -0.45 & 0.35 & 0.48 & 0.40 & 0.12 & 0.29 & 0.37 & 0.41 & - & -0.35 \\
\hline \%drip & -0.43 & 0.43 & 0.41 & -0.49 & -0.44 & -0.49 & -0.37 & -0.62 & -0.77 & -0.56 & -0.35 & - \\
\hline \multicolumn{13}{|c|}{ After heat shock } \\
\hline SFA & - & -0.99 & -0.99 & 0.84 & 0.94 & 0.93 & 0.11 & 0.41 & 0.54 & 0.27 & 0.30 & -0.40 \\
\hline MUFA & -0.99 & - & 0.99 & -0.84 & -0.94 & -0.92 & -0.11 & -0.40 & $-\mathbf{0 . 5 3}$ & -0.28 & -0.30 & 0.39 \\
\hline PUFA & -0.99 & 0.99 & - & -0.80 & -0.92 & -0.90 & -0.11 & -0.40 & $-\mathbf{0 . 5 3}$ & -0.27 & -0.29 & 0.36 \\
\hline$T_{\mathrm{m}}$ & 0.84 & -0.84 & -0.80 & - & 0.94 & 0.98 & 0.08 & 0.34 & 0.49 & 0.30 & 0.30 & -0.60 \\
\hline $\mathrm{SFC}_{\mathrm{ag}}$ & 0.94 & -0.94 & -0.92 & 0.94 & - & 0.97 & 0.10 & 0.39 & 0.54 & 0.32 & 0.40 & -0.51 \\
\hline $\mathrm{SFC}_{\mathrm{fr}}$ & 0.93 & -0.92 & -0.90 & 0.98 & 0.97 & - & 0.09 & 0.38 & 0.53 & 0.28 & 0.30 & -0.56 \\
\hline$D_{4,3} \operatorname{mix}$ & 0.11 & -0.11 & -0.11 & 0.08 & 0.10 & 0.09 & - & 0.79 & 0.64 & 0.68 & -0.08 & 0.03 \\
\hline$D_{4,3}$ ice & 0.41 & -0.40 & -0.40 & 0.34 & 0.39 & 0.38 & 0.79 & - & 0.93 & 0.68 & 0.02 & -0.29 \\
\hline \%aggr & 0.54 & -0.53 & $-\mathbf{0 . 5 3}$ & 0.49 & 0.54 & 0.53 & 0.64 & 0.93 & - & 0.76 & -0.03 & -0.49 \\
\hline$\% \mathrm{fat}_{\text {extr }}$ & 0.27 & -0.28 & -0.27 & 0.30 & 0.32 & 0.28 & 0.68 & 0.68 & 0.76 & - & -0.07 & -0.23 \\
\hline Hardness & 0.30 & -0.30 & -0.29 & 0.30 & 0.40 & 0.30 & -0.08 & 0.02 & -0.03 & -0.07 & - & -0.09 \\
\hline \%drip & -0.40 & 0.39 & 0.36 & -0.60 & -0.51 & -0.55 & 0.03 & -0.29 & -0.49 & -0.23 & -0.10 & - \\
\hline
\end{tabular}

of fat destabilization during freezing. These results are contradictory to the findings of Adleman and Hartel [2], who observed the highest fat destabilization for milk fat with a low melting point. However, the used milk fat in their experiment contained
$36 \%$ solid fat at $5{ }^{\circ} \mathrm{C}$, compared to only $17 \%$ solid fat in this experiment, which may explain the different findings.

In addition to the positive correlation between SFC and fat destabilization, a significant positive correlation could be observed 
between the particle size of the ice cream mix and the particle size, the percentage of aggregates and the percentage of solvent extractable fat of ice cream (Tab. III). Therefore, the homogenization pressure also seemed to influence fat destabilization, because larger globules are more exposed to shear forces, which resulted in more coalescence of the fat phase. Koxholt et al. [17] also observed larger fat globules and agglomerates in ice cream when using lower homogenization pressures $(0 / 0$ and $5 / 1 \mathrm{MPa})$, while Schmidt and Smith [23] found no differences in fat destabilization between 3.5 and $14 \mathrm{MPa}$, although a lower fat destabilization could be determined for high homogenization pressures $(28.1 \mathrm{MPa})$.

\subsection{Hardness of ice cream as a function of milk fat composition, homogenization pressure, ageing temperature and storage conditions}

For consumers, hardness is an important quality parameter of ice cream. Therefore, this parameter was measured for fresh ice cream and after heat shock as a function of milk fat type, homogenization pressure and ageing temperature (Tab. IV). In this experiment, milk fat type was described by SFA, MUFA, PUFA, melting point and SFC of the bulk fat, while the homogenization pressure by the particle size of the mix. When all these methods in addition to the methods describing ice cream were correlated with the data of hardness, a Pearson correlation matrix could be obtained for both fresh ice cream and after heat shock. In Table III, it is shown that the hardness of fresh ice cream was significantly positively correlated with SFA proportion, SFC of the bulk fat and the percentage of solvent extractable fat. Since parameters related to fat destabilization were not correlated with hardness, it seemed that the hardness of fresh ice cream is only determined by the fatty acid composition of the used milk fat. When investigating the correlation for hardness after heat shock, it appeared that none of the measured parameters could be significantly correlated, suggesting that other phenomena such as ice crystals are dominating hardness of heat-shocked ice cream.

When comparing these results with the literature, Schmidt and Smith [23] did not observe any influence of homogenization pressure on the hardness, while Muse and Hartel [20] reported a significant contribution of the amount of destabilized fat. The latter provided a network between the air cells in the ice cream which resulted in an increased hardness of ice cream. Abd El-Rahman et al. [1] reported no significant differences in hardness between different milk fat fractions, which is in contrast with the results of this experiment. Finally, they detected a reduction in hardness after storage of ice cream, which was supported by our results.

\subsection{Melting behaviour of ice cream as a function of milk fat composition, homogenization pressure, ageing temperature and storage conditions}

In addition to hardness, the melting behaviour of ice cream is also an important quality parameter for consumers. Melting behaviour was monitored by measuring drip loss at $20^{\circ} \mathrm{C}$ after $150 \mathrm{~min}$ as a function of milk fat type, homogenization pressure and ageing temperature for fresh ice cream and after heat shock (Tab. IV). Simultaneously, structure retention during melting was investigated of which some results are shown in Figure 3. Similar to the discussion of hardness, a Pearson correlation matrix was calculated for both fresh ice cream and after heat shock (Tab. III). It appeared that drip loss in fresh ice cream was significantly negatively correlated with SFA proportion, SFC of bulk fat and all parameters describing fat destabilization, while particle 
Table IV. Hardness $(N)$ at $-15{ }^{\circ} \mathrm{C}$ and percentage of drip after 150 min at $20{ }^{\circ} \mathrm{C}$ for ice cream made from control milk fat (C), milk fat enriched with unsaturated fatty acids (U), a low-melting milk fat fraction $(\mathrm{L})$ and a high-melting milk fat fraction $(\mathrm{H})$ for different levels of homogenization pressure and ageing temperature on fresh ice cream and after heat shock. Results are expressed as mean

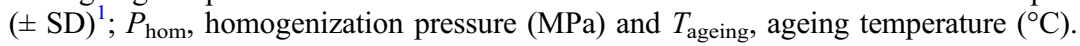

\begin{tabular}{|c|c|c|c|c|c|c|}
\hline \multirow[t]{2}{*}{ Milk fat } & \multirow{2}{*}{$\begin{array}{l}P_{\text {hom }} \\
(\mathrm{MPa})\end{array}$} & \multirow{2}{*}{$\begin{array}{l}T_{\text {ageing }} \\
\left({ }^{\circ} \mathrm{C}\right)\end{array}$} & \multicolumn{2}{|c|}{ Fresh ice cream } & \multicolumn{2}{|c|}{ After heat shock } \\
\hline & & & $\begin{array}{l}\text { Hardness } \\
(N)\end{array}$ & $\begin{array}{c}\text { \%drip } \\
\text { (150 min) }\end{array}$ & $\begin{array}{l}\text { Hardness } \\
(N)\end{array}$ & $\begin{array}{c}\text { \%drip } \\
\text { (150 min) }\end{array}$ \\
\hline \multirow[t]{6}{*}{$\mathrm{C}$ ice cream } & $5 / 5$ & 7 & $27.0 \pm 7.3$ & $14.6 \pm 1.5$ & $27.9 \pm 3.9$ & $13.9 \pm 2.2$ \\
\hline & & 2 & $59.4 \pm 9.1$ & $13.3 \pm 4.1$ & $22.6 \pm 6.8$ & $16.9 \pm 0.1$ \\
\hline & $13 / 5$ & 7 & $6.6 \pm 1.3$ & $20.7 \pm 1.7$ & $27.3 \pm 4.6$ & $13.3 \pm 2.0$ \\
\hline & & 2 & $40.5 \pm 6.0$ & $16.7 \pm 4.7$ & $28.3 \pm 6.2$ & $12.6 \pm 1.4$ \\
\hline & $20 / 5$ & 7 & $36.2 \pm 6.1$ & $8.9 \pm 3.1$ & $19.6 \pm 2.6$ & $9.6 \pm 0.5$ \\
\hline & & 2 & $41.8 \pm 7.2$ & $24.5 \pm 0.8$ & $-^{2}$ & $23.1 \pm 2.8$ \\
\hline \multirow[t]{6}{*}{$\mathrm{U}$ ice cream } & $5 / 5$ & 7 & $25.7 \pm 9.9$ & $13.6 \pm 2.6$ & $24.2 \pm 4.2$ & $15.5 \pm 1.4$ \\
\hline & & 2 & $48.6 \pm 9.1$ & $9.8 \pm 2.7$ & $26.7 \pm 14.6$ & $14.5 \pm 2.7$ \\
\hline & $13 / 5$ & 7 & $14.7 \pm 6.7$ & $22.3 \pm 4.0$ & $24.0 \pm 3.5$ & $14.1 \pm 0.9$ \\
\hline & & 2 & $31.9 \pm 4.7$ & $28.1 \pm 8.3$ & $32.3 \pm 4.9$ & $10.7 \pm 1.3$ \\
\hline & $20 / 5$ & 7 & $21.2 \pm 3.8$ & $10.4 \pm 2.8$ & $25.9 \pm 3.5$ & $9.7 \pm 0.7$ \\
\hline & & 2 & $42.8 \pm 10.8$ & $20.1 \pm 1.2$ & $-^{2}$ & $18.3 \pm 1.2$ \\
\hline \multirow[t]{6}{*}{$\mathrm{L}$ ice cream } & $5 / 5$ & 7 & $20.5 \pm 5.1$ & $21.6 \pm 3.3$ & $19.4 \pm 3.1$ & $24.3 \pm 2.9$ \\
\hline & & 2 & $24.7 \pm 7.8$ & $16.2 \pm 3.5$ & $19.7 \pm 5.0$ & $23.2 \pm 1.1$ \\
\hline & $13 / 5$ & 7 & $23.0 \pm 6.9$ & $33.2 \pm 5.6$ & $21.2 \pm 3.3$ & $26.2 \pm 2.5$ \\
\hline & & 2 & $31.3 \pm 7.5$ & $28.6 \pm 5.4$ & $39.5 \pm 11.5$ & $18.5 \pm 2.8$ \\
\hline & $20 / 5$ & 7 & $29.1 \pm 5.6$ & $16.0 \pm 1.9$ & $15.5 \pm 2.8$ & $16.8 \pm 1.0$ \\
\hline & & 2 & $38.2 \pm 4.8$ & $32.3 \pm 1.9$ & $-^{2}$ & $43.6 \pm 4.5$ \\
\hline \multirow[t]{6}{*}{$\mathrm{H}$ ice cream } & $5 / 5$ & 7 & $38.8 \pm 6.2$ & $8.4 \pm 0.8$ & $30.9 \pm 4.1$ & $9.1 \pm 0.4$ \\
\hline & & 2 & $54.8 \pm 6.4$ & $10.0 \pm 3.0$ & $22.7 \pm 10.5$ & $11.6 \pm 1.3$ \\
\hline & $13 / 5$ & 7 & $28.6 \pm 6.7$ & $31.0 \pm 4.1$ & $29.5 \pm 5.5$ & $28.1 \pm 6.2$ \\
\hline & & 2 & $49.3 \pm 7.3$ & $16.2 \pm 1.8$ & $41.4 \pm 5.6$ & $15.1 \pm 1.6$ \\
\hline & $20 / 5$ & 7 & $42.3 \pm 16.2$ & $10.2 \pm 5.1$ & $20.1 \pm 4.4$ & $7.2 \pm 1.8$ \\
\hline & & 2 & $42.6 \pm 3.9$ & $12.2 \pm 3.3$ & $-^{2}$ & $16.1 \pm 3.2$ \\
\hline
\end{tabular}

${ }^{1}$ Hardness, mean of 30 determinations and \%drip, mean of 3-4 determinations.

2 Data are lost because of technical problems with texture analyser.

size of the ice cream mix was not significantly correlated. These results are confirmed in Figure 3, which showed that for ice cream with a high SFC and a high amount of fat destabilization, the structure of ice cream was strongly retained. For ice cream after heat shock, however, less significant correlations could be observed. Only a high SFC of the bulk fat and a high percentage of aggregates could significantly reduce drip loss, suggesting that fat destabilization was still important after heat shock to reduce drip loss.

All these findings are confirming the model of Koxholt et al. [17], who postulated that if the fat agglomerates in the unfrozen serum phase reach sizes above a critical diameter they block the foam lamellae and impede the drainage. But, this effect depends on the lamella width and therefore on the air 

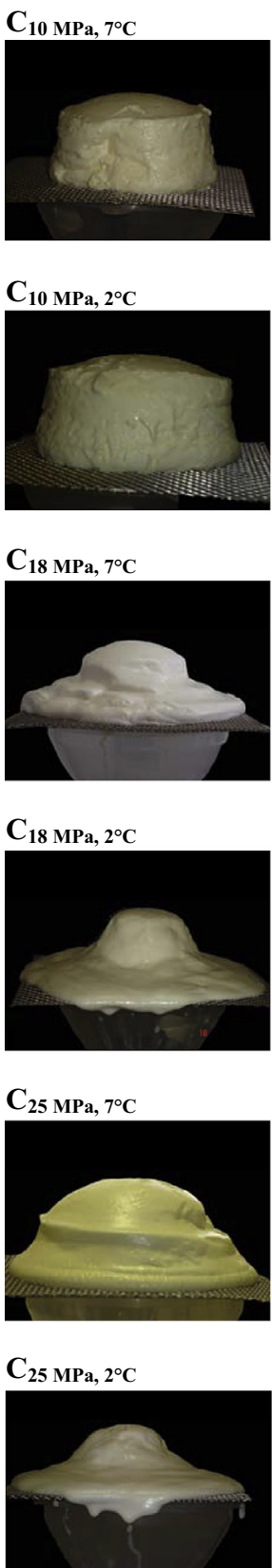
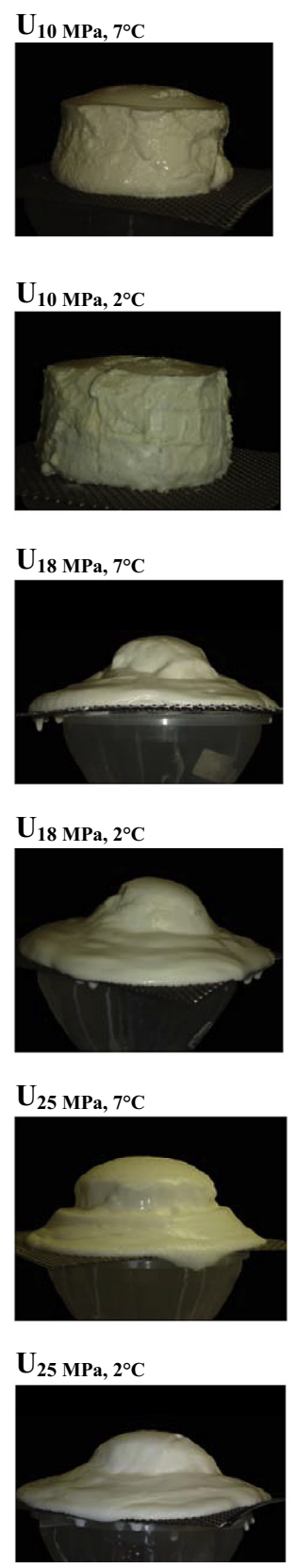
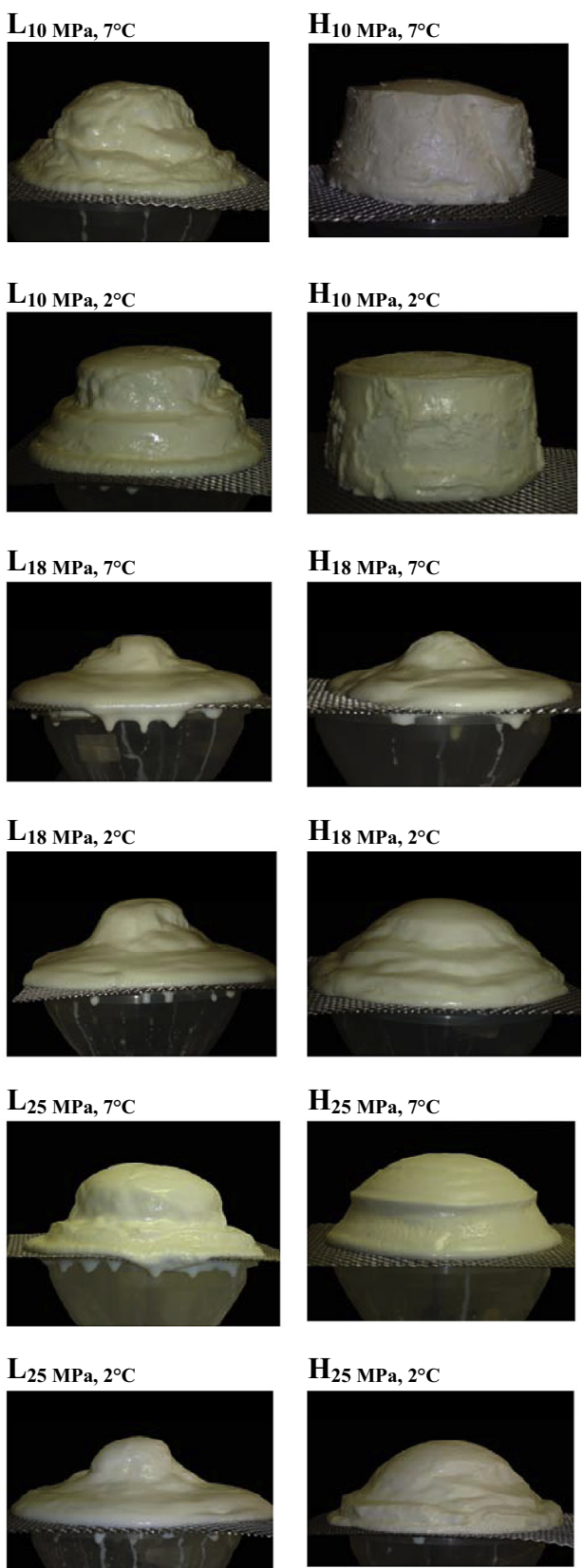

Figure 3. Structural retention after 150 min melting at $20{ }^{\circ} \mathrm{C}$ for fresh ice cream from control milk fat $(\mathrm{C})$, milk fat enriched with unsaturated fatty acids (U), a low-melting milk fat fraction (L) and a high-melting milk fat fraction $(\mathrm{H})$ for different levels of homogenization pressure $(10,18$ and $25 \mathrm{MPa})$ and ageing temperature $\left(7\right.$ and $\left.2{ }^{\circ} \mathrm{C}\right)$. 
bubble size and the overrun. In addition, Abd El-Rahman et al. [1] reported a slower melting behaviour for ice cream produced from milk fat with a high melting point, and Nazaruddin et al. [21] observed a faster melting behaviour for ice cream produced from vegetable fats rich in unsaturated fatty acids. When comparing different homogenization pressures, the meltdown behaviour was not affected over a wide range, although the optimal pressure depends on the individual composition and the demands on quality parameters such as the mouth feel [17].

\subsection{Sensorial quality of ice cream as a function of milk fat composition, homogenization pressure, ageing temperature and storage conditions}

Finally, a trained taste panel was asked to evaluate ice cream samples for hardness, mouth feel, melting behaviour and preference. Because of large variations between individual panelists, it was not evident to confirm significant differences between ice cream samples for all conditions. Therefore, the most significant trends will be described.

When comparing the different milk fats, milk fat $\mathrm{H}$ was considered as the significantly hardest ice cream with the slowest melting behaviour for some process conditions $\left(20 / 5 \mathrm{MPa}\right.$ at $7^{\circ} \mathrm{C}$; and $5 / 5 \mathrm{MPa}$ at $7{ }^{\circ} \mathrm{C} ; 5 / 5 \mathrm{MPa}$ at $2{ }^{\circ} \mathrm{C}$ ), while none of the other milk fats could consistently be referred to as softest ice cream or as the ice cream with the most rapid melting behaviour. No significant trends could be observed for mouth feel and no specific preference could be reported for none of the milk fats.

In addition to a comparison between the different milk fats, the influence of different homogenization pressures was investigated for milk fat $\mathrm{C}$ and $\mathrm{U}$ before and after heat shock. Treatment ' $13 / 5 \mathrm{MPa}$ ' showed the most stable results with intermediate values for hardness, mouth feel and melting behaviour. In contrast, a significantly stickier mouth feel and slower melting behaviour could be reported for treatment ' $20 / 5 \mathrm{MPa}$ ', which was also reflected by a reduced preference for this treatment. Treatment ' $5 / 5 \mathrm{MPa}$ ' was considered as the softest ice cream with the fastest melting behaviour and the most watery mouth feel, although these trends could not be confirmed for all process conditions.

The influence of the ageing temperature was also investigated. Ice cream aged at $7{ }^{\circ} \mathrm{C}$ was considered as softer and more watery ice cream, although no significant preference could be reported for one of both treatments.

Finally, the taste panel was asked for their preference of ice cream. When comparing ice cream produced with different milk fats or at different ageing temperatures, none was significantly more preferred. However, when comparing ice cream produced with different homogenization pressures, ice cream produced at $20 / 5 \mathrm{MPa}$ was appreciated less.

\section{CONCLUSIONS}

Ice cream was prepared with different milk fats using different process conditions. A high SFC and low homogenization pressures correlated well with large particles and high amounts of solvent extractable fat, which resulted in firm ice cream with a slow melting behaviour and good structure retention. In contrast, ageing temperature did not significantly influence fat destabilization. Following heat shock, the results suggested that the hardness of ice cream was not determined by any of the parameters investigated, but was probably dominated by the amount of ice crystals. A good melting behaviour of ice cream was retained after heat shock, provided that a strong matrix of destabilized fat was produced during the freezing process. 
Even though differences could be observed in hardness and melting behaviour for different milk fats or different process conditions, these differences were hardly identified by trained sensory panels. These results suggest that it is possible to produce high-quality ice cream with an altered fatty acid composition without any alteration in the conventional production process of ice cream, provided that ice cream is stored and consumed under ideal circumstances.

Acknowledgements: This work was funded by a grant of the Institute for Agricultural and Fisheries Research. We are grateful to Claudine Roels for assistance with the practical laboratory work. We also thank Royal FrieslandCampina (Klerken, Belgium) for the anhydrous milk fat.

\section{REFERENCES}

[1] Abd El-Rahman A.M., Madkor S.A., Ibrahim F.S., Kilara A., Physical characteristics of frozen desserts made with cream, anhydrous milk fat, or milk fat fractions, J. Dairy Sci. 80 (1997) 1926-1935.

[2] Adleman R., Hartel R.W., Lipid crystallization and its effect on the physical structure of ice cream, in: Garti N., Sato K. (Eds.), Crystallization Processes in Fats and Lipid Systems, Marcel Dekker, New York, USA, 2001, pp. 381-427.

[3] Anonymous, KB 11.06.2004 - Royal Decree concerning consumption ice, Het Belgisch Staatsblad (2004) 57035-57038.

[4] Bazmi A., Launay B., Cuvelier G., Relkin P., Impact of crystalline milk fat on rheological properties of ice cream mix emulsions during aging time at $4{ }^{\circ} \mathrm{C}$, J. Texture Stud. 39 (2008) 309-325.

[5] Bolliger S., Kornbrust B., Goff H.D., Tharp B.W., Windhab E.J., Influence of emulsifiers on ice cream produced by conventional freezing and low-temperature extrusion processing, Int. Dairy J. 10 (2000) 497-504.

[6] Boode K., Bisperink C., Walstra P., Destabilization of $\mathrm{O} / \mathrm{W}$ emulsions containing fat crystals by temperature cycling, Colloid Surf. 61 (1991) 55-74.
[7] Clarke C., The science of ice cream, 1st edn., The Royal Society of Chemistry, Cambridge, UK, 2004.

[8] Crilly J.F., Russell A.B., Cox A.R., Cebula D.J., Designing multiscale structures for desired properties of ice cream, Ind. Eng. Chem. Res. 47 (2008) 6362-6367.

[9] Darling D.F., Recent advances in the destabilization of dairy emulsions, J. Dairy Res. 49 (1982) 695-712.

[10] Dewhurst R.J., Shingfield K.J., Lee M.R.F., Scollan N.D., Increasing the concentrations of beneficial polyunsaturated fatty acids in milk produced by dairy cows in high-forage systems, Anim. Feed Sci. Technol. 131 (2006) 168-206.

[11] Goff H.D., Colloidal aspects of ice cream - a review, Int. Dairy J. 7 (1997) 363-373.

[12] Goff H.D., Verespej E., Smith A.K., A study of fat and air structures in ice cream, Int. Dairy J. 9 (1999) 817-829.

[13] ISO, Milk and milk products, specification of Mojonnier-type fat extraction flasks, Standard 3889, International Organization for Standardization, Geneva, Switzerland, 2006.

[14] Kaylegian K.E., Hartel R.W., Lindsay R.C., Applications of modified milk fat in food products, J. Dairy Sci. 76 (1993) 1782-1796.

[15] Kokubo S., Sakurai K., Hakamata K., Tomita M., Yoshida S., The effect of manufacturing conditions on the de-emulsification of fat globules in ice cream, Milchwissenschaft 51 (1996) 262-265.

[16] Kokubo S., Sakurai K., Iwaki S., Tomita M., Yoshida S., Agglomeration of fat globules during the freezing process of ice cream manufacturing, Milchwissenschaft 53 (1998) 206-209.

[17] Koxholt M.M.R., Eisenmann B., Hinrichs J., Effect of the fat globule sizes on the meltdown of ice cream, J. Dairy Sci. 84 (2001) 31-37.

[18] Kramer A., Kahan G., Cooper D., Papavasiliou A., Non-parametric ranking method for the statistical evaluation of sensory data, Chem. Senses Flavour 1 (1974) 121-133.

[19] Mensink R.P., Zock P.L., Kester A.D.M., Katan M.B., Effects of dietary fatty acids and carbohydrates on the ratio of serum total to HDL cholesterol and on serum lipids and apolipoproteins: a meta-analysis of 60 controlled trials, Am. J. Clin. Nutr. 77 (2003) 1146-1155. 
[20] Muse M.R., Hartel R.W., Ice cream structural elements that affect melting rate and hardness, J. Dairy Sci. 87 (2004) 1-10.

[21] Nazaruddin R., Syaliza A.S., Wan Rosnani A.I., The effect of vegetable fat on the physicochemical characteristics of dates ice cream, Int. J. Dairy Technol. 61 (2008) 265-269.

[22] Sakurai K., Kokubo S., Hakamata K., Tomita M., Yoshida S., Effect of production conditions on ice cream melting resistance and hardness, Milchwissenschaft 51 (1996) 451-454.

[23] Schmidt K.A., Smith D.E., Effects of varying homogenization pressure on the physical properties of vanilla ice cream, J. Dairy Sci. 72 (1989) 378-384.

[24] Smet K., Raes K., De Block J., Herman L., Dewettinck K., Coudijzer K., A change in antioxidative capacity as a measure of onset to oxidation in pasteurized milk, Int. Dairy J. 18 (2008) 520-530. 